\title{
Challenges and opportunities of breeding and genetic improvement of durum wheat in Russia
}

\author{
P.N. Mal'chikov ${ }^{1 *}$, M.A. Rozova ${ }^{2}$, A.I. Ziborov², M.G. Myasnikova ${ }^{1}$, T.V. Chakheeva ${ }^{1}$ \\ 1 Samara Research Institute of Agriculture named after N.M. Tulaikov, Bezenchuk, Russia \\ ${ }^{2}$ Federal Altai Scientific Centre of Agro-BioTechnologies, Barnaul, Russia
}

DOI 10.18699/ICG-PlantGen2019-67

(c) Autors, 2019

* e-mail: sagrs-mal@mail.ru

\begin{abstract}
Favorable soil and climatic environments of Russia are not sufficiently used for the production of high-quality grain of durum wheat. It is caused by a lower efficiency of its cultivation compared to other cereals. The development of varieties adapted to environmental fluctuations in the zones of their cultivation, with high grain quality, is taken as one of the major factor to solve the problem. Based on many-year experiments a breeding strategy for adaptation is suggested. It roots in the possibility to reinforce specific (regional) homeostasis with the genetic systems of cultivars living on a vast area, which are carriers of non-specific homeostasis, as well to increase resistance to diseases (foliar blights, blotches, stem rust, powdery mildew) and to lodging. Ways to enhance grain quality due to the use of germplasm with high levels of protein, gluten and carotenoid content are put forward. Problems of strengthening gluten quality of Russian durum wheat cultivars are discussed. For these purposes, cultivars from Italy, Canada and Australia should be widely used as basic material and the corresponding biochemical markers of the GLi-B1d, Glu-B1d, Glu-A3d loci would be quite valuable.

Key words: durum wheat; homeostasis; gluten quality; biochemical markers.
\end{abstract}

\section{Introduction}

Durum wheat acreage in Russia is $0.6-0.7$ million ha and $0.7-0.9$ million tons of grain is produced (data for the past 5 years), which is one-third as much as 30 years ago. The decline in durum wheat production took place at the transition of the economy towards market relations and was determined by a lower efficiency of its cultivation (demands in high agronomic requirements, decreased tolerance to stresses, necessity of additional inputs) compared to other cereals. Breeding can solve the problems to a large extent. Over the past decade, an increase in durum wheat cultivation area has been observed (Figure 1).

\section{Breeding rates}

At the moment, 45 cultivars are included in the State Register of Protected Breeding Achievements of Russia. Over the past 10 years, 14 cultivars have been registered, which is comparable to the results of the previous 10 years, when 16 varieties were registered. Thus, the intensity of the breeding process were not changed for long periods. This is because of the practices used (methods of traditional breeding) and the lack of increase in breeding scale (number of laboratories, volume of breeding material). Acceleration and the enhancement of breeding output are possible through the wide utilization of diploid technology of germplasm development and application of methods of marker-assisted selection (Leonova, 2013).

\section{Breeding activities}

\subsection{Adaptivity and stability of grain yield}

In Russia, durum wheat breeding has gone through several stages: from the first breeding cultivars selected from local landraces through the period of monopolistic cultivars cultivated in several regions on large areas ('Melanomus 69',
'Hordeiforme 10', 'Hordeiforme 189', 'Kharkovskaya 46', 'Bezenchukskaya 139', and 'Altaika') and up to the modern stage of the formation of local systems of cultivars. The first and foremost task of the perspective development of breeding is the improvement of the systems. The strategy is based on the use of cultivars living on a vast area, which carry gene blocks for adaptation and non-specific homeostasis, as basic genotypes. At the same time, regional cultivars of local value should be used as donors of genes for specific homeostasis (optimal vegetation period for the zone, stem parameters, heat- and drought tolerance, response to soil environments etc.). An ecological and geographic study of nurseries of the Kazakhstan-Siberian net of wheat improvement (KASIB), which consisted of the genotypes developed in Russia and Kazakhstan, was carried out at 9 ecological sites in 2015-2017. It appeared that 13 cultivars of different origin should be considered as forms living on a vast area. They are 'Leucurum 1307d-54', 'Leucurum 1469d-21', 'Leucurum 1594d-3', 'Leucurum 1429d-10', 'Leucurum 1506d-36', 'Hordeiforme 1591d-21' (Samara Research Institute of Agriculture), 'Hordeiforme 18585-2' (Scientific and Production Center of Soil Management and Plant Science), 'Hordeiforme 950/899' (Karabalyk Agricultural Research Station), 'Hordeiforme 01-115-5', 'Hordeiforme 05-42-12'(Omsk Agrarian Scientific Center), 'Kargala 66', 'Kargala 223' (Aktyubinsk Agricultural Research Station), 'Hordeiforme 178-05-2' (Scientific and Production Center of Grain Farming) (Mal'chikov, Rozova et al., 2018).

\subsection{Resistance to diseases}

The following diseases are common to the Russian regions where durum wheat is cultivated: foliar blights (Septoria, Pyrenophora, Bipolaris, Alternaria, Fusarium, powdery mildew (Blumeria graminis), stem rust (Puccinia graminis f.sp.tritici), 


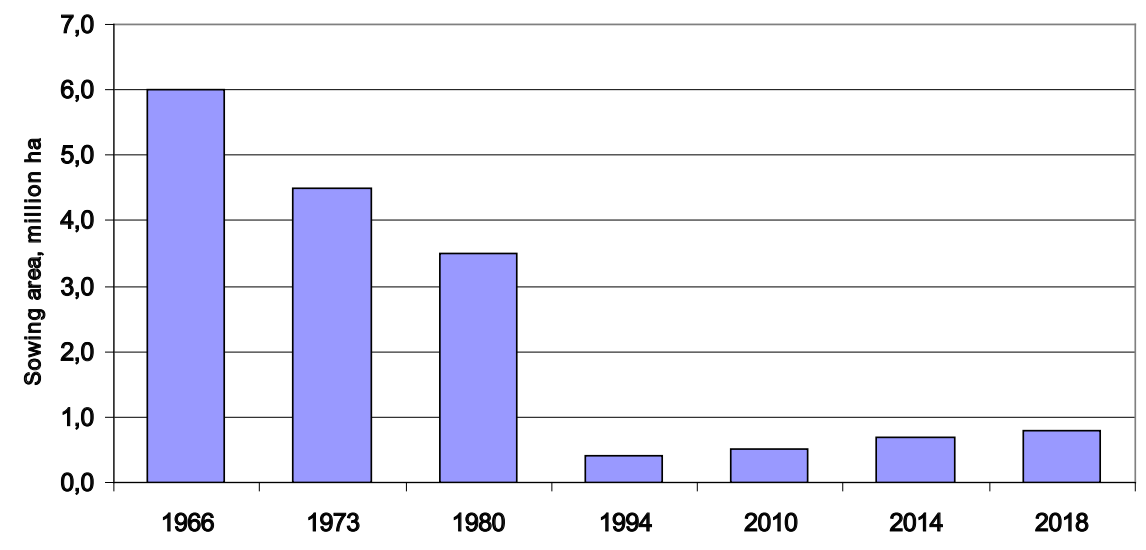

Figure 1. Dynamics of durum wheat sowing area in 1966-2018. leaf rust (Puccinia triticina Eriks.), Fusarium head blight (Fusarium spp.), black point (Alternaria alternata, Alternaria tenuis, Bipolaris sorokiniana) (Koishibaev, 2018). Pathogen species mostly have regional localization. Septoria spp., Puccinia graminis f.sp.tritici, Bipolaris sorokiniana, the agents of black points, occur more often in Western Siberia and in Altai. In the Volga region, epiphytoties of foliar diseases caused by Fusarium spp. and Pyrenophora occur frequently. In these regions, an effective breeding is carried out to develop resistance to the complexes of pathogens based on the formation of corresponding QTLs. Breeding on resistance to powdery mildew is effective in all breeding centers. Genetic donors of the trait are forms of durum wheat with translocations from another wheat species (Tr. dicoccum, Tr. timopheevii) and introgression of resistance from foreign cultivars (Italy, CIMMYT etc.). The problem of durum wheat resistance to leaf rust is most relevant for North-Caucasus region (Al'derov et al., 2000). The hazard of the disease in steppe regions seldom reaches the economic threshold, even in epiphytotic years. A sufficient number of resistant sources can be identified among local breeding lines and released cultivars adapted to local environmental constrains. The development of stem rust resistant cultivars is aggravated by the deficiency of a sufficient set of adapted parental stock at breeders' disposal. To solve the matter, donors from CIMMYT and possibilities of the KASIB program (the study and identification of resistant genotypes) have been involved.

\subsection{Incorporation of Rht genetic systems}

At present, in the State Register of Protected Breeding Achievements of Russia, the drought-tolerant reduced-height cultivars 'Bezenchukskaya zolotistaya' and 'Bezenchukskaya 210 ' are included. They carry the gene for plant height reduction RhtAnh (Anhinga, CIMMYT), which decreases the height by $15 \%$. The genetic system of plant height reduction in 'Omskaya yantarnaya' and 'Yasenka' has a similar effect. 'Bezenchukskaya 209' and the Italian cultivar 'Rusticano' carry a strong gene, $R h t B 1 b$. A new short-statue variety, 'Triada' $(R h t B 1 b)$, is promising for North-Caucasus, CentralChernozem regions and for Siberia (Mal'chikov, Sidorenko et al., 2017). Taking this into account, there is a real perspective to decrease durum wheat plant height almost in all regions of its breeding and cultivation (Table 1).

\subsection{Grain protein content}

This characteristic is in close correlation with gluten content and it determines $40 \%$ of the overall grain quality. It is controlled by the polygenic systems and depends to a great extent on environments. In the majority of Russian regions where durum wheat is cultivated, climate and soils enable the accumulation of more than $14 \%$ of protein in grain (Rozova, Mukhin, 2015; Mal'chikov et al., 2017). In favorable environments, for the trait to happen, this level can be reached by almost all cultivars. The problem of protein content in wheat grain as a breeding trait becomes more complicated for its negative correlation with grain yield. Nevertheless, there is a varietal differentiation. Mapping of the large-effect QTL on the 6B chromosome transferred from Tr. dicoccoides allowed analogues QTL to be identified in some other varieties (Joppa, Cantrell, 1990; Joppa et al., 1997). A possible way to overcome or to weaken the sharp contradiction of the trait with yield can be through the inclusion of "strong" gene blocks covering high protein content. Among modern Russian commercial cultivars, 'Solnechnaya 573', 'Oazis', 'Saratovskaya zolotistaya', 'Pamyatie Yanchenko', 'Salyut Altaya', 'Omsky korund', 'Bezenchukskaya krepost”, 'Altaiskaya niva' stably form grains with a high protein content (Mal'chikov, Rozova et al., 2017). It is assumed that the cultivars carry a block of genes from $T r$. dicoccum or local varieties (landraces) and its effect can be similar to that of QTL on 6B chromosome of Tr. dicoccoides.

\subsection{Gluten quality}

Allele " $c$ " (according to the catalogue developed by A.M. Kudryavtsev, 1994) of the Gli-B1 ${ }^{d}$ locus containing electrophoretic component $\gamma-45$, closely linked with low-molecular glutenin of the second type (LMW-2), which functionally provides a good quality of gluten, occurs in the population of Russian commercial cultivars at a frequency of $0.46 \%$. This complex enables the formation of gluten strength at a value of $35-45 \mathrm{ml}$ after the SDS-sedimentation, test depending on environments. But the gluten index of such cultivars does not exceed $65 \%$, which does not correspond to the demands of modern industrial production of high quality pasta. Genetic systems, which include alleles $7+8$ and $6+8$ at the $G l u-B 1^{d}$ locus responsible for high-molecular subunits of glutenin, in combination with allele " $a$ " (after the nomenclature by Nieto - Taladriz et al., 
Table 1

Target regions for the adoption of short-statue cultivars

\begin{tabular}{lll}
\hline Genetic system of $R h t$ & Ecologically adapted donors of Rht genetic systems & Target regions \\
\hline RhtAhn & $\begin{array}{l}\text { Bezenchukskaya zolotistaya, Bezenchukskaya 210, } \\
\text { Pamyatie Chekhovicha }\end{array}$ & Volga region, Urals, Siberia, Altai \\
QTL & Omskaya yantarnaya & Siberia, Altai, Urals \\
QTL & Yasenka & North Caucasus, Volga region \\
RhtB1b & Bezenchukskaya 209, Triada & North Caucasus, Volga region, \\
& & Central Chernozem region, Altai \\
\hline
\end{tabular}

Table 2

Carotenoid content in grain of durum wheat cultivars of different countries, Bezenchuk, 2017-2018

\begin{tabular}{llll}
\hline Cultivar & Origin & Carotenoid content & \% to St. \\
\hline Bezenchukskaya zolotistaya, st. & & $\rho \rho m$ & 100.0 \\
Bezenchukskaya krepost' & Samara & 8.7 & 92.8 \\
Saratovskaya zolotistaya & Samara & 8.07 & 83.5 \\
Bezenchukskaya 210 & Saratov & 7.3 & 74.4 \\
Elizavetinskaya & Samara & 6.47 & 83.3 \\
Omsky korund & Saratov & 7.25 & 66.7 \\
Donela M & Omsk & 5.8 & 78.2 \\
Oazis & Rostov & 6.8 & 63.2 \\
Average over Russian cultivars & Altai & 5.5 & 80.6 \\
Achille & & 7.01 & 42.1 \\
Grecalle & Italy & 3.66 & 60.9 \\
Maestrale & Italy & 5.3 & 60.9 \\
Duroflaus & Italy & 5.3 & 83.9 \\
Duromax & Austria & 7.3 & 59.4 \\
Odisseo & Austria & 5.17 & 66.7 \\
Tamaroi & Italy & 5.8 & 62.0 \\
Hyperno & Australia & 5.39 & 92.1 \\
Average over foreign cultivars & Australia & 8.01 & 66.0 \\
HCP 0.05 & & 5.74 & \\
\hline & & 0.32 & \\
\hline
\end{tabular}

1997) in the Glu-A3 ${ }^{d}$ locus responsible for the low-molecular subunits of glutenin, allow the gluten index to be increased to $70-85 \%$ (Porceddu, Blanco, 2014). There is no published information on gluten indexes or on the profile of the Glu-A3, Glu-B1 allele loci of modern Russian cultivars (Shevchenko, Mal'chikov et al., 2018). Therefore, it is necessary to study the matters and to transfer effective alleles from cultivars of Italy, Canada and Australia.

\subsection{Carotenoid content in grain}

Russian commercial cultivars include an essential part of genotypes with high contents of carotenoid pigments. In environments of Volga region, the cultivars 'Saratovskaya zolotistaya', 'Bezenchukskaya zolotistaya', and 'Bezenchukskaya krepost" accumulate 5.5-9.0 $\rho \rho \mathrm{m}$ of yellow pigment, which is significantly more than do foreign varieties from Italy, Canada and Austria (Table 2). Nowadays, intensive breeding on the base of Russian original material is being carried out in a number of laboratories of Russian scientific centers: the Research Institute of Agriculture of the South-East (Saratov), the Samara Research Institute of Agriculture (Bezenchuk), Federal Altai Scientific Centre of Agro-BioTechnologies (Barnaul), Omsk Agrarian Scientific Center. To enhance the efficiency of the breeding direction, it is necessary to identify and to marker the corresponding QTL for the substantiation and application of MAS technologies.

\section{References}

Alderov A.A. Intraspecific diversity and genetic control of resistance of hard wheat to leaf rust. Proceedings on Applied Botany, Genetics and Breeding. 2000;158:37-40 (in Russian).

Joppa L.R., Cantrell R.G. Chromosomal location of genes for grain protein content of wild tetraploid wheat. Crop Sci. 1990;30(5):10591069.

Joppa L.R., Du C., Hart G.E., Harland G.A. Mapping gene(s) for grain protein in tetraploid wheat (Trticum turgidum L.) using a 
population of recombinant inbred chromosome lines. Crop Sci. 1997;37(5):1586-1589.

Kudryavtsev A.M. Genetics of gliadin of spring durum wheat (Triticum durum Desf.). Rus. J. Genet. 1994;30(1):77-84. (in Russian)

Koyshibaev M. Wheat diseases. Ankara: Food and Agriculture Organization of the United Nations (FAO). 2018;366 p.

Leonova I.N. Molecular markers: implementation in crop plant breeding for identification, introgressions and gene pyramiding. Vavilov J. Genet. Breed. 2013;17(2):314-325. (in Russian)

Mal'chikov P.N., Sidorenko V.S., Myasnikova M.G., Rozova M.A., Mudrova A.A., Tsygankov V.I., Mukhitov L.A. The results of breeding of spring durum wheat varieties with a shortened stem length. Zernobobovye i krupanie kul'tury. 2017:4:97-106. (in Russian)

Malchikov P.N., Rozova M.A., Myasnikova M.G., Shabolkina E.N. Protein accumulation in durum grain depending on genotype and environment. Izvestia Samara Scientific Center Russian Academy Sciences. 2017;19(2-4):620-628. (in Russian)

Mal'chikov P.N., Rozova M.A., Morgunov A.I., Myasnikova M.G., Zelensky Yu.I. Yield performance and stability of modern breeding stock of spring durum wheat (Triticum durum Desf.) from Russia and Kazakhstan. Vavilov. J. Genet. Breed. 2018;22(8):939-950.

Nieto-Taladriz M.T., Ruiz M., Martinez M.C., Vazquez J.F., Garillo J.M., Variation and classification of B low-molecular weight glutenin subunit alleles in durum wheat. Theor. Appl. Genet. 1997;95:1155-1160.

Porceddu E., Blanco A. Evolution of durum wheat breeding in Italy. Proceed. International Symposium of genetics and breeding of durum wheat. 2014;110:157-173.

Rozova M.A., Mukhin V.N. The influence of weather conditions on the content of protein, gluten and its quality in spring durum wheat grain in the conditions of the forest-steppe of the Altai region. Achievements Sci Technol. 2015;29(8):58-61. (in Russian)

Shevchenko S.N., Mal'chikov P.N., Myasnikova M.G., Natoli V., DeVita P., Giuliani M. Genetic methods for improving the quality of durum wheat adapted to the climatic conditions of Russia with special emphasis on grain commercial characteristics Izvestia Samara Scientific Center Russian Academy Sciences. 2018;20(2-2):220-230.

Conflict of interest. The authors declare no conflict of interest. 